$$
\text { Prugberger Tamás - Rácz Zoltán }
$$

\title{
A munka- és a közszolgálati jogi érdekérvényesítés alakulása 2010 után $^{1}$
}

\section{The Development of Legal Enforcement in Labour Law and Public Service Law After 2010}

\section{Összefoglalás}

A tanulmány a témakört érintô jogelméleti kérdések tisztázását követôen bemutatja, hogy a munkaügyi kapcsolatok egyes intézményeinél miként rendezi az új Munka törvénykönyve, a módosított közalkalmazotti törvény, valamint a szintén új köztisztviselői törvény a szakszervezeti érdekvédelmet, az érdekegyeztetést, a kollektív szerzôdést, a kollektív érdekvitákat és a sztrájkot. A vizsgálat nemcsak a gazdasági kollektív munkajogra, hanem a közalkalmazotti és a közszolgálati jog munkaügyi kapcsolataira is kiterjed.

Journal of Economic Literature (JEL) kódok: J51, J52, J31, J83, K31

Kulcsszavak: érdekegyeztetés, érdekvédelmi szervezetek, munkáltatói szövetség, kollektív szerzôdés, közvetítés, döntôbíráskodás, sztrájk

\section{Summary}

After clarifying the relevant questions of legal theory, the study presents the way the new Labour Code, the modified Public Service Law and the new Civil Service Law regulate works councils, interest protection by trade unions, interest reconciliation, collective agreements, collective interest disputes and strikes at the various institu-

Prof. EM. DR. Prugberger Tamás, DSc, Miskolci Egyetem (prugberger.tamas@ t-online.hu), DR. Rácz Zoltán, PhD, egyetemi docens, Miskolci Egyetem Munkajogi és Agrárjogi Tanszék (civracz@uni-miskolc.hu). 
tions of labour relations. In addition to economic collective labour law, it also covers labour relations in public service and civil service law.

Journal of Economic Literature (JEL) codes: J51, J52, J31, J83, K31

Keywords: interest reconciliation, advocacy organisations, employers' association, collective agreement, mediation, arbitration, strike

\section{AlAPKÉRDÉSEK}

A munkajog magánjogi (civilisztikai) része két nagy területből, az individuális és a kollektív munkajogból áll. Az individuális munkajogviszony alanyai a munkáltató és a munkavállaló, ahol a munkavégzéssel kapcsolatos konkrét jogviszony tartalmát a munkaszerzôdés határozza meg. Mivel a munkajogviszonyban ténylegesen egy alá-fölé rendelt helyzet érvényesül, ahol a munkavállaló a munkáltató lazább vagy kötöttebb utasításai és ellenôrzési tevékenysége mellett köteles a munkaszerzódésbôl fakadó feladatait elvégezni, és ezen túlmenôen, a munkavállaló anyagilag és egzisztenciálisan a munkáltatótól függ, ezért ezt az alá-fölé rendelt helyzetet van hivatva kiegyenlíteni a kollektív munkajog, vagyis a munkaügyi kapcsolatok joga. A nyugat-európai államokban a közszolgálati jogban is fennáll a kollektív közszolgálati jog. A köztisztviselôknek is vannak szakszervezeteik, amelyek a köztisztviselők érdekében az óket foglalkoztató állami-önkormányzati és köztestületi szervezetekkel kollektív szerzôdést kötnek, képviseletükben bértárgyalásokat folytatnak, hasonlóképpen a közszolgálat munkakörülményeirôl is. Az egyes hivatalokon belül pedig az ott dolgozó köztisztviselók és közalkalmazottak közhivatalnoki, illetve közalkalmazotti tanácsot alakíthatnak az üzemi tanácsok mintájára (Peine-Heinlein, 1999:168-169; Ojeda Aviles-Perez, 1989:384; Heerma van Voss, 2011:189-207). Bár az Európai Szociális Megállapodás 1. cikkelye csak a munkáltatói és a munkavállalói oldal közötti szociális párbeszéd kialakításának a kötelezettségét írja elố a tagállamok részére, azt viszont, hogy ezt milyen módon valósítják meg, a nemzeti jogalkotás hatáskörébe helyezi (Lentner-Parragh, 2016:35). Ennek ellenére a nyugat-európai tagállamok többsége a gazdasági munka világában kialakult érdekegyeztetéshez és kollektív szerződéses, megállapodásos rendszerhez hasonlót alakított ki a közszolgálatban is (Peine-Heinlein, 1999:168-169; Ojeda AvilesPerez, 1989:384; Heerma van Voss, 2011:189-207). ${ }^{2}$

A munkaügyi kapcsolatok joga, ezt is figyelembe véve, ugyancsak két nagy területból áll, ahol az egyik az ún. érdekegyeztetés joga, másképpen a koalíció joga, míg a másik az üzemi és a közszolgálati alkotmányjog. Az érdekegyeztetés jogának alanyai egyfelől a munkáltatói szövetségek, vállalati szinten pedig a munkáltató, másfelól pedig a szakszervezetek. A közszolgálat esetében a munkáltatói szövetség helyett mindig az adott közületi szerv vagy annak felettes szerve áll szemben a szakszervezettel, illetve a szakszervezeti szövetséggel. Itt a két fél közötti érdekösszhang megvalósításának az 
Prugberger Tamás - Rácz Zoltán: A munka-és a közszolgálati jogi érdekérvényesités...

eszköze a koalíciós tárgyalások fórum- és intézményrendszere, valamint e tárgyalások eredményeként létrejövố kollektív szerzôdés (a továbbiakban: ksz.). Amennyiben a tárgyalások nem vezetnek sikerre, és úgy túnik, hogy a ksz.-kötés meghiúsul, annak érdekében, hogy a tárgyalások mégis folytatódjanak, és létrejöjjön a megállapodás, az egymással szemben álló felek pártatlan külsô szakértố és bíráló személy vagy bizottság segítségével közvetítésben, egyeztetésben vagy döntôbíráskodásban megnyilvánulva, érdekvitát bonyolíthatnak le, aminek eredménytelensége esetén a szemben álló munkaügyi érdekvédelmi szervezetek munkaküzdelmet folytathatnak egymással szemben. Ennek keretében a munkavállalók és érdekképviseleti szerveik sztrájkhoz, a munkáltatók és szövetségeik pedig kizáráshoz (lock out) folyamodhatnak. A munkaküzdelemnek azonban ez a két formája a köztisztviselók esetében csak egyes országokban megengedett, mint pl. Franciaországban, azonban a fegyveres testületek tagjai és a fốhivatalnokok ott sem sztrájkolhatnak, Németországban és Ausztriában pedig köztisztviselố egyáltalán nem sztrájkolhat. ${ }^{3}$ Ez alól Magyarország annyiban jelent kivételt, hogy a közszolgálat kettébomlik attól függóen, hogy a közszolgáló hatósági tevékenységet ellátó közintézménynél vagy hatósági tevékenységet nem folytató közintézménynél dolgozik. ${ }^{4} \mathrm{Az}$ előbbinél az érdemi tevékenységet köztisztviselók látják el, akik nem sztrájkolhatnak, míg az egyéb közintézményeknél dolgozó közalkalmazottaknál a sztrájk nincs megtiltva. ${ }^{5}$

A kollektív munkajog hazai általános szabályait és alkalmazásuk elveit az új Munka törvénykönyve (Mt.) Általános rendelkezések XIX. fejezete tartalmazza. A Szociális Chartával és az 1991. évi Akcióprogrammal összhangban deklarálja a koalíciós jogi szervezkedés szabadságát. Bár az érdekvédelmi szervezôdést az Mt. 151. §-a az említettek szerint biztosítja, sốt feljogosítja az érdekvédelmi szervezeteket arra, hogy szövetségeket hozzanak létre, valamint ilyen szövetségekhez csatlakozhassanak, a munkáltatónál pedig a szakszervezetek és szövetségeik képviseletet létesíthessenek, ennek ellenére a multi- és internacionális cégek, fóleg az amerikai szemlélet hatására, gyakran meghiúsítják e jogosultság érvényesülését (Prugberger-Szebehelyi, 1996).

A 233. § rendezi a tájékoztatás és a konzultáció intézményét. E szakasz a tájékoztatás alatt „a munkaügyi kapcsolatokkal, valamint a munkaviszonnyal összefüggó, törvényben meghatározott információ munkáltatói részrốl történô átadását, megismerését, megvizsgálását”, munkáltatói oldalról pedig „az ezzel kapcsolatos vélemény kialakítását" érti. Konzultáció pedig megállapodási célkitúzéssel oly módon folytatható le, hogy biztosítva legyen a felek megfelelô képviselete, a közvetlen személyes véleménycsere, valamint az érdemi tárgyalás. E szakasz kimondja még azt is, hogy a konzultáció idôtartama alatt, de a kezdeményezéstôl számított 7 napig, különmegállapodással azonban szerintünk ennél hosszabb ideig is a munkáltató tervezett intézkedése nem hajtható végre.

E deklarált munkavállalói érdekérvényesítési jogosítványokat azonban a 234. § alapján a munkavállalók hátrányára a munkáltatók - különösen a Magyarországot a közép-európai régió országaival együtt mintegy gyarmatként kezeló multik - az új Mt.-t érintố kodifikációs munkálatok során jelentôsen szúkíteni tudták. A 234. § felmenti a munkáltatót a szakszervezet és az üzemi tanács (továbbiakban: üt.) irányában 
fennálló tájékoztatási kötelezettség alól, ha a „tájékoztatással bizalmas adatok, technológiák és információk kerülnének nyilvánosságra”, amelyek a munkáltatót hátrányos helyzetbe hoznák. A tájékoztatáskorlátozásnak a 234. § (2) bekezdés elsô mondatában lefektetett indoka gyenge lábon áll, tekintve, hogy a második mondata az EU régi tagállamaihoz hasonlóan elóírja a szakszervezeti képviseletnek és a szakszervezeti tisztségviselôknek valamennyi információ üzleti titokként történô kezelését. Éppen ezért a tájékoztatásnak és a konzultációnak ilyen jellegú korlátozása a nyugat-európai államokban ismeretlen fogalom. Az új magyar Mt.-ben megfogalmazott e korlátozással fennáll a tájékoztatás és a konzultáció teljes betiltásának a lehetôsége, hacsak a rendeltetésellenes joggyakorlás tilalmát a bíróságok nem fogják ilyen esetekben alkalmazni. Ezért indokolt lenne, hogy a Kúria közigazgatási-munkaügyi kollégiuma ilyen tartalmú állásfoglalással elejét vegye a joggal való visszaélés ilyesfajta formájának.

Ez azért is fontos lenne, mert - miként erre Lentner Csaba és Parragh Bianka már hivatkozott, érdekegyeztetésrôl, konszenzuskeresésrôl és participációról szóló cikke is utal - a kormány ismét elôtérbe állította a háromoldalú megállapodáscentrikus érdekegyeztetést, amelyben az érdekegyeztetés során „egyensúlyozó szerep” betöltésére és „arányos” érdekkiegyenlítés elérésére törekszik a szociális partnerek körében. A szerzőpáros ezzel összefüggésben helyesen utal arra, hogy a korábbi Országos Érdekegyeztetô Tanácsban (OÉT) ez az érdekegyeztetés nem múködött sem eredmény-, sem költséghatékonyan, egyrészt a hozzátelepített hivatali szervezet nagyfokú bürokratizmusa, másrészt a megkötött megállapodásoknak a kormány- és az ellenzéki politika részérôl, a parlamenti képviselôk felhasználásával történt kijátszása miatt (Lentner-Parragh, 2016:34). Abban viszont eltér a véleményünk a szerzôpárosétól, hogy a 2010 elốtti országos háromoldalú érdekegyeztetés túl szúk lett volna, amit az OÉT helyébe lépett Nemzeti Gazdasági Társasági Tanács (NGTT) létrejötte kiszélesített. A kiszélesítés valóban megtörtént, azonban megszúnt az érdekegyeztetési megállapodáskötés lehetôsége, mivel a NGTT hatásköre csak konzultációra, véleményezésre és információra szúkült le. Ezenkívül pedig túl sok szervezet került be ebbe a tanácsba, olyan is, amelynek tevékenysége távol áll a munka és a közszolgálat világától, ezért az NGTT-ben folyó tárgyalások a foglalkoztatással kapcsolatos szociális partnerek és az általuk képviseltek számára teljesen érdektelenek. Nem véletlen, hogy a kormány - miként erról még szó esik - informális módon újból visszatért a megállapodásos bértárgyalásokra. Abban viszont igaza van a szerzôpárosnak, hogy összességében a társadalmi érdekegyeztetés szélesedett (Lentner-Parragh, 2016:85), azonban bizonyos fokig felszínessé vált.

\section{A MUNKAÜGYI ÉRDEKKÉPVISELETI SZERVEZETEK}

A gazdasági munka világában

Az új Mt. XXI. fejezete a korábbi Mt.-hez hasonlóan csak a szakszervezetet - mint érdekképviseleti szervezetet -, valamint annak jogait és kötelezettségeit szabályozza, a munkáltatói szövetségekét nem. Ez annyiban lehet problematikus, hogy míg a szak- 
Prugberger Tamás - Rácz Zoltán: A munka- és a közszolgálati jogi érdekérvényesítés...

szervezeti jogok és kötelezettségek ténylegesen meghatározottak, és így a munkáltatói szövetségek számára köztudottá válik a szakszervezetek és szövetségeik mozgás- és játéktere, addig a munkáltatói szövetségeknél ilyen behatárolás nincsen. Ennélfogva korlátlanabb a munkáltatói érdekképviseleti szervezeteknél a jogi lehetôségekkel való élés terjedelme. Ez viszont az egyenlő bánásmód és az esélyegyenlôség törvényileg meghatározott elvét sérti (2003:XXV. tv.). Míg ugyanis az Mt. a szakszervezeti hovatartozás, valamint a kívülállás tekintetében a megkülönböztetés tilalmát kimondja, hasonló tilalmi rendelkezést a munkáltatói szövetségekre nézve nem tartalmaz. Ez pedig munkáltatói érdekeket is sérthet.

A szakszervezet fogalmát a 270. § akként határozza meg, hogy minden olyan szervezet, amelynek „elsôdleges” célja a munkavállalói érdekek védelme, ilyennek minôsül. Az „elsôdleges” szó kiszélesíti a célhoz kötöttséget, ami a relatív jogképesség kitágításával járhat. Így a szakszervezet minden olyan tevékenységet kifejthet, amit bármely egyesület vagy akár a pártok is. Ez viszont aligha áll összhangban a kollektív munkaügyi védelem Európa-jogi felfogásával. Továbbá ez a szakasz szakszervezetnek tekinti a munkáltatónál múködô nem önálló szakszervezeti egységet, valamint a szakszervezeti tisztséget betöltố személyt is. A szakszervezetek és a szövetségeik munkáltatókkal szembeni védelme érdekében a 271. § kimondja, hogy a munkáltató nem követelheti, hogy a munkavállaló szakszervezeti hovatartozásáról nyilatkozzon, és a munkavállaló alkalmazását vagy jogviszonyának megszüntetését nem teheti attól függôvé, hogy tartozik-e szakszervezethez, és ha igen, akkor melyikhez. Ezen az alapon tilos megkülönböztetést tenni a munkavállalók között a bánásmód és juttatások tekintetében is. Mindezt igen helyes volt rögzíteni, mivel a gyakorlatban, fóleg a multinacionális vállalatoknál, éppen az ellenkezóje, a szakszervezeti szervezôdés megtiltása, valamint a szakszervezeti tagok és tisztségviselôk munkaviszonyának körmönfont indokokkal történô megszüntetése, kilépésre kényszerítése érvényesül.

A 272. § kilenc pontban fogalmazza meg a szakszervezetek jogait. A jogok megfogalmazása nagyjában megegyezik a korábbi Mt.-ben szerepeltekkel, amely azonban tartalmazta a kollektívszerzôdés-kötési jogosultságot és az olyan munkáltató területére történó belépési jogot, ahol a szakszervezetnek munkaviszonyban álló tagja van. A kollektívszerzôdés-kötési jogosultságot az új Mt. a kollektív szerzôdésekrôl szóló XXII. fejezetben rendezi, míg a munkáltató területére történó belépési jogot a 275. §-ban, elkülönítve a 272. §-ba foglalt jogosultságoktól. A korábbi Mt.-ben a jogosultságok együttes rendezése a jelenlegihez viszonyítva szerencsésebb volt. A munkáltató területére történô belépési jogosultság új megfogalmazásával összefüggésben meg kell jegyezni, hogy elmaradt a korábbi elôzetes bejelentési kötelezettség. Ez annyiban jó, hogy egy hirtelen megjelenés mellett a munkáltatónak nincs ideje és lehetôsége kozmetikázni és eltussolni olyan tényeket és körülményeket, amelyekkel a munkavállalók jogos érdekeit megsértik. Ezzel egyúttal a munkaügyi ellenôrzés is eredményesebbé válhat. Elôzetes bejelentési kötelezettség ezért álláspontom szerint csak akkor áll fenn, ha ebben a szakszervezettel meg tud állapodni. Értelemszerúen kétoldalú megállapodás szükséges a szakszervezeti tagdíj levonásához és a szakszervezet részére történô átutaláshoz is, amelyért a munkáltató díjazást nem igényelhet. A francia Code 
du travail kimondja, hogy ha a munkáltató a nála képviselettel rendelkezô egyik szakszervezetnek levonja és átutalja a tagdíjakat, nem tagadhatja meg a nála képviselettel rendelkezô többi szakszervezettôl sem. Ezt azonban külön kimondani szükségtelen, mivel ez következik a 271. §-nak előbb már bemutatott elóírásaiból. ${ }^{6}$

A 273. $§$ a korábbi Mt.-hez viszonyítva jóval szúkebbre vette a választott és a szakszervezet által önállónak minôsített telephelyen dolgozó szakszervezeti tagok ügyeinek intézésére megbízott tisztségviselók munkahelyi státuszvédelmét. A védelem ugyanis a tisztségviseloot és a nagyobb létszámú alkalmazottakkal dolgozó, önálló telephelyen múködő, több szakszervezeti megbízott közül csak egyet illet meg a tisztség/ megbízatás betöltésének idejére, valamint azt követően nem egy év, hanem csak hathavi idôtartamra, de csak akkor, ha szakszervezeti tisztségét/megbízatását legalább 12 hónapon át betöltötte. A védelmi idôszaknak eme leszúkítése mellett a szakszervezeti tisztségviselő/megbízott egzisztenciális védelme annyira gyenge, hogy nem mer hatékonyan fellépni a munkáltatói önkényeskedésekkel szemben, ami ugyancsak igen gyakori, fóleg a multiknál (Prugberger-Szebehelyi, 1996, 9. jegyzet).

A munkáltatói intézkedésekkel szembeni szakszervezeti vétóemelés lehetôségét és a vele kapcsolatos eljárást, ideértve a nyolc napon belüli indokkal ellátott kifogásemelést, a 173. § (5) bekezdése tartalmazza. E szakaszból azonban kimaradt a kifogásolt intézkedés végrehajtásának az egy hétig tartó tárgyalások idejére történô átmeneti felfüggesztése, mely a korábbi Mt.-ben szerepelt. Ez a megszorítás szintén csak a munkáltatók érdekeit védi a munkáltatókkal szemben. Az intézkedés átmeneti felfüggesztése ugyanis a cég gazdasági érdekeit nem szokta befolyásolni, mert a termelésre és a kereskedelmi tevékenységre nem hat ki, az ebből eredő feszültség azonban igen.

A szakszervezeti tisztségviselốt munkahelyen megilletô munkaidô-kedvezményt a 274. §, a korábbi Mt.-hez képest, szintén szúkítette, mivel az egy évre szóló összes munkaidő-kedvezmény mindössze két szakszervezeti tag után havi egy óra, és azt a szakszervezet által megjelölt munkavállaló veheti igénybe, amelynek idôpontját, rendkívül indokolt eset kivételével, 5 nappal korábban kell bejelenteni. A munkaidô-kedvezmény korábban pénzben megváltható volt, amelyet szakszervezeti célokra kellett felhasználni. Az új Mt. (4) bekezdésében ezt a lehetôséget elvonta. Figyelmet érdemel még az (5) bekezdés új megfogalmazása is, mely szerint nemcsak munkaidó-kedvezmény idejére jár távolléti díj, hanem a konzultáció tartamára is. Konzultációnak minôsül álláspontunk szerint a munkaküzdelem (sztrájk és kizárás) ideje alatt folytatott tárgyalás is. Ennélfogva érvényét kell hogy veszítse az a korábbi gyakorlat, mely szerint a szakszervezet részérôl kiküldött tárgyaló delegációnak a tárgyalások idôtartamára nem jár ellátás, vagyis távolléti díj. Hogy ezzel ne lehessen visszaélni, és a tárgyalásokkal az idôt húzni, indokolt lenne, ha a bírói gyakorlat a távolléti díjjal díjazott tárgyalási idôtartamot hét munkanapban állapítaná meg.

A szakszervezetek részérôl az itt tárgyalt jogok gyakorlásának két alapvetô feltétele van. Az egyik a reprezentativitás, ami azt jelenti, hogy egy munkahelyen vagy egy adott ágazatban, területen a munkavállalók legalább 10\%-a tagsági jogviszonnyal hozzá tartozzon. A másik pedig a koalíció-, illetve a tarifaképesség. Ez a nyugat-európai államokban annyit jelent, hogy az adott érdekvédelmi szervezet ne függjön az ellenérdekú fél- 
Prugberger Tamás - Rácz Zoltán: A munka-és a közszolgálati jogi érdekérvényesités...

tốl, harmadik hatalomtól, valamint az államtól (Söllner, 1969:57, 117-120). A magyar Mt. korábbi elốírással egyezóen most is csak az ellenérdekú féltôl való függetlenséget kívánja meg. Ebbốl már sok visszás helyzet alakult ki, mivel pártlistán szakszervezeti és munkáltató szövetségi vezetốk egyaránt bekerültek a parlamentbe, és ha a pártjuk a tagszervezetük érdekeivel ellentétes szavazást kívánt meg, azt teljesíteniük kellett. Ezt a problémát azonban az országgyúlési választásokról szóló új törvény megoldotta, mivel eltörölte a pártlistás szavazást.

\section{A közszolgálatban}

A közalkalmazottak jogállásáról szóló törvény (Kjt). és a közszolgálati tisztviselôkrốl szóló törvény (Kttv.) egyaránt szól a szakszervezetekrốl. A szakszervezetek mind a közalkalmazottak, mind pedig a köztisztviselôk körében is jogosultak érdekvédelmi tevékenységet kifejteni, bár bizonyos fokig korlátozottabb jelleggel, mint amilyen érdekvédelmi tevékenységet kifejthetnek a gazdasági munka világában. Ennek ellenére a közszolgálatban múködô szakszervezetek a tapasztalatok szerint Magyarországon sokkal hatékonyabb és eredményesebb érdekvédelmi tevékenységet tudnak kifejteni, mint azok, amelyek a gazdasági munka világában múködnek. Ennek kettôs oka van. Az egyik ok, hogy a munkavállalók félnek a szakszervezetbe történố belépéstôl, mivel a munkáltatók többsége nem nézi azt jó szemmel. A másik ok pedig az, hogy a gazdasági életben múködố szakszervezetek általában gyengébbek, mint azok, amelyek a közszolgálat területén mûködnek. A közszolgálat területén is a szakszervezetek nagyjából hasonló módon fejtik ki érdekvédelmi tevékenységüket, mint a gazdasági életben, bár kevesebb jogosítvánnyal rendelkeznek, különösen a köztisztviselôi szférára vonatkoztatva. A Kjt. 6. §-a értelmében ágazati szinten a tárcavezetô, valamint az önkormányzatoknál az önkormányzat a döntéshozatal elốtt köteles a megfeleló közalkalmazotti szakszervezetekkel egyeztetést lefolytatni, és figyelembe venni a szakszervezeti javaslatokat a foglalkoztatást és az illetményeket érintô döntések elôtt. A szakszervezeteknek e kérdésekben véleményezési joguk van. Ugyanez érvényes a közalkalmazottak nagyobb csoportját érintô intézkedési tervezetek esetében is. A szakszervezetek részéról egyet nem értés esetén azonban nem áll fenn a határozattervezet meghozatalát érintô átmeneti felfüggesztés és esetleges döntôbíróság elé való utalás, ami most már az új Mt. esetében sincsen meg. A köztisztviselôi szférában a szakszervezetet az itt említett kérdésekben csak javaslattételi jog illeti meg, és csak félévente köteles a foglalkoztató szerv információt adni a köztisztviselôket érintố szociális és foglakoztatási kérdésekról. Mindezt figyelembe véve az lenne a helyes, ha ugyanazok a jogosultságok illetnék meg a közalkalmazotti és a köztisztviselôi szférában múködô szakszervezeteket is, mint amelyekkel a szakszervezetek a gazdasági munka világában rendelkeznek. Ugyanakkor azonban nem szabad figyelmen kívül hagyni, hogy az új Mt., a munkáltatóknak kedvezve, a korábbi Mt.-ben megállapított szakszervezeti jogosítványokat jelentôsen szúkítette. Ezért az eredetileg megállapított szakszervezeti jogosítványokat indokolt lenne visszaállítani, amelyek összhangban voltak a nyugat-európai szakszervezeti jogosítványokkal. ${ }^{7}$ 
Ami a közszolgálatban múködô szakszervezetek érdekvédelmi tevékenységgel öszszefüggố részvételi jogosultságát, vagyis a reprezentativitási feltételeket illeti, sokkal egyszerúbb, mint amit az Mt. elôír a gazdasági munkaügyi kapcsolatokra vonatkozóan. Ennek részletes szabályait a közszolgálati érdekegyeztetéssel összefüggésben tárgyaljuk a két intézmény szoros kapcsolódása miatt.

A KOLLEKTíV MUNKAJOGI ÉS KÖZSZOLGÁLATI ÉRDEKEGYEZTETÉSI TÁRGYALÁSOK RENDSZERÉNEK ÚJ SZABÁLYAI

A gazdasági munkajogban

A 2009-ben az országos érdekegyeztetésról elfogadott LXXII. tv. tripartit (háromoldalú), az ágazati és a területi érdekegyeztetésrôl elfogadott LXXIII. tv. pedig bipartit (kétoldalú) jelleggel rendezte az érdekegyeztetést egy közel két évtizede tartó, óriási joghézagot megszüntetve. A 2009:LXXII. tv. szerint az Országos Érdekegyeztetô Tanácsba (OÉT) szakszervezeti oldalról az kerülhetett be, amely négy nemzetgazdasági ágazatban, valamint tizenkét alágazatban tevékenykedô tagszervezettel, illetve területi vagy megyei szervezetekkel rendelkezik. Tagszervezeteitôl pedig megkövetelte, hogy legalább 150 munkáltatónál munkahelyi szervezettel rendelkezzenek. A munkáltatói szövetségek részére e törvény pedig azt írta elő, hogy legalább két nemzetgazdasági ágazatban és hat alágazatban tagszervezettel, tagszervezetei pedig három régióban vagy tíz megyében területi szervezettel rendelkezzen. Ezenkívül tagszervezeteinek tagságát legalább ezer olyan vállalkozás alkossa, amely minimum 100 fốt foglalkoztat. Végezetül mind a két oldalon feltételként szerepelt a megfelelô európai szövetségi tagság.

Ez a megoldás lényegében a holland Nemzeti Gazdasági és Szociális Tanács reprezentatív kritériumrendszerének az átvétele, csak igen bürokratikus és túlkomplikált jelleggel. ${ }^{8}$ Sokkal helyesebb lett volna a szintén holland/belga megoldásból kiinduló bolgár megoldás átvétele, ahol az Országos Munkaügyi Tanácsba bekerülés feltétele szakszervezeti szövetségi részrôl 50 ezres tagsággal való rendelkezés, és az adott ágazatot egyedül vagy más szakszervezettel 51\%-os arányban képviselje. Munkáltatói szövetségi részról pedig feltétel az 500 taggal való rendelkezés, és a szakszervezeti szövetséghez hasonlóan, az adott ágazat 51\%-os lefedése (Sredkova, 1995:256-257).

A 2010. áprilisi parlamenti választásokat követôen hatalomra került Fidesz-KDNPkormány javaslatára, az Országgyúlés a 2011:XCIII. tv.-nyel hatályon kívül helyezte a 2009:LXXII. tv.-t, és az Országos Érdekegyeztetô Tanács (OÉT) helyett megalkotta a Nemzeti Gazdasági és Társadalmi Tanácsot (NGTT). E testületbe - miként ezt fentebb érintettük - a korábbi szakszervezeti és munkáltatói szövetségi, valamint munkaügyekért felelôs minisztériumi oldalon túlmenôen bekerültek az egyházak, a nemzeti önkormányzatok és a különbözó gazdasági, lakossági, fogyasztói és környezetvédelmi érdekképviseleti szervezetek. Ezzel az NGTT elvesztette munkaügyi érdekképviseleti jellegét, ezenkívül pedig csak konzultatív, tájékoztató és javaslattevő testületté alakult át, ahol országos jellegú kollektívszerzôdés-kötésre nincsen mód. Ezzel a kormány a 
Prugberger Tamás - Rácz Zoltán: A munka-és a közszolgálati jogi érdekérvényesités...

minimálbér meghatározását, valamint a munkával és a szociális ügyekkel kapcsolatos jogszabályok meghozatalát saját hatáskörében egyedül vált jogosulttá rendezni.

Ahogy erre már utaltunk, az NGTT ennélfogva egy igen nagyra duzzadt konzultációs testületté vált, amely éppen a túlságosan nagy mérete és igen széles területet átfogó jellege miatt, jelenlegi formájában egy nem kellóen hatékony intézmény. Ugyanakkor a benne való részvételi jogosultság diszkriminatív jellegú, mivel a munkáltatói szövetségek részvételi jogosultsága azokhoz a már bírált reprezentativitási feltételekhez van kötve, amelyeket a hatályon kívül helyezett 2009:LXXII. tv. alkotott meg. E túlkombinált bürokratikus feltételrendszert a 2011:XCIII. tv. változatlanul átvette, ugyanakkor a NGTT-ben részvételi jogosultsággal rendelkezô többi érdekvédelmi szervezetnél ilyen reprezentatív feltételek nincsenek elôírva. Megítélésünk szerint az OÉT-t Nemzeti Munkaügyi Tanácsként vissza kellene állítani azzal, hogy abban állami részvétellel tripartit döntés is hozható, valamint háromoldalú kollektív szerzôdés (ksz.) is köthetô. Ez megfelelne az Európai Törvényszék gyakorlatának is, amelynek állásfoglalása szerint irányelv ilyen módon is implementálható. Ezzel együtt - miként ez a legtöbb nyugat-európai országban fennáll - a központi munkaügyi hivatalt az országos foglalkoztatáspolitikai tanács, míg az egyes megyei hivatalokat szintén a hasonló megyei foglalkoztatásügyi tanácsok irányítása alá kellene visszaállítani, ahol az állam, illetve a szakminisztérium/szakállamtitkárság a szakszervezeti és a munkáltatói szövetség képviselôjével együtt gyakorolná az irányítást, és határozná meg a hivatal múködésének stratégiáját. Addig is azonban, amíg erre sor nem kerül, ki lehetne alakítani egy olyan gyakorlatot, hogy a NGTT keretein belül a munkaügyi szociális partnerek, a munkaügyekért felelôs miniszterrel/államtitkárral együtt, a maguk körében döntést hozhassanak, és országos ágazatközi ksz.-t is köthessenek. Ezzel együtt meglenne a lehetôség az elsố Fidesz-kormányzat idején megalkotott ama megoldáshoz, amikor az akkor létrehozott Nemzeti Gazdasági és Társadalmi Tanács mellett a Nemzeti Munkaügyi Tanács is párhuzamosan múködött, és ahol az NGTT-ben a Nemzeti Munkaügyi Tanács két koalíciós oldalának is hivatalból képviselete volt. Ezt a rendszert kellene visszaállítani, amely hasonlított a holland Nemzeti Gazdasági és Szociális Tanács struktúrájához.

Áttérve az ágazati és a területi érdekegyeztetésre, itt a változatlanul hatályban maradt 2009:LXXIII. tv. kimondja, hogy az ágazati párbeszéd bipartit (kétoldalú) intézmény, amelyben az állam nem vesz részt, csak a szakszervezetek és a munkáltatói érdekvédelmi szervezetek, amelyek ágazati, alágazati és szakágazati párbeszédbizottságokat alkotnak. Elvileg területi párbeszédbizottságok is létesíthetôk, ilyenek megalakítására azonban eddig még nem került sor. E törvény kimondja, hogy a párbeszédbizottság (pb.) jogi személy. A tv. az ágazati pb.-ban való részvételt szintén reprezentativitási feltételekhez köti, amelyeket szintén vagy egyénileg, vagy konföderációba lépve kell teljesíteni. ${ }^{9}$

A tv. szakszervezeti részrốl három alternatív feltételt ír elô: 1. Az adott ágazatban legalább tíz olyan munkáltatónál legyen képviselete, ahol a munkavállalók 10\%-a nála tagsági viszonyban áll; 2. legalább három olyan munkáltatónál képviselete legyen, ahol a tagjainak a létszáma a munkavállalók $10 \%$-át eléri; vagy 3 . ha csak egy vál- 
lalatnál van képviselete, ott a tagjainak a létszáma elérje a munkavállalói létszám több mint 50\%-át. A törvény munkáltatói oldalról két feltételt ír elô, ugyancsak alternatív módon. Az egyik, hogy a munkáltatói szövetségnek legalább 40 munkáltatói tagja legyen, vagy pedig olyan vállalat legyen a tagja, amely az adott ágazatban a munkavállalók több mint 50\%-át tömöríti. E reprezentativitási feltételrendszer alapvetôen jó.

Az ágazati, alágazati és szakágazati párbeszédbizottságok már nemcsak tanácskozási és véleménynyilvánítási jogkörrel rendelkeznek, hanem döntési és megállapodáskötési jogkörrel is. Éppen ezért helyes lenne, ha az ágazati párbeszéd nemcsak bipartit jelleggel, hanem állami részvétellel tripartit módon is folyhatna. Ugyanis ez esetben egy egész országos ágazatra kiterjedő, háromoldalú döntéssel vagy ksz.-szel, a már említett európai kúriai (EC) gyakorlat alapján, implementálható lenne nemcsak általános, hanem ágazati jellegú irányelv is.

\section{A közszolgálati jogban}

A közszolgálati joganyagnak mind a közalkalmazottak, mind pedig a köztisztviselók jogi helyzetének 2011. évi, átfogó módosítása elôtt, a közalkalmazotti és a köztisztviselői szférát egyaránt érintve átfogó, országos és területi érdekegyeztetési rendszer volt hatályban, amit a Kjt. és a Ktv. egymással „összekapcsolódó” módon rendezett. A közszolgálatnak mind a két területét átfogta a Kjt. II. részének (Munkaügyi kapcsolatok) Országos ágazati és területi érdekegyeztetés alcím alatti, 4-6/B-ig terjedô szakasza, valamint a Ktv.-nek a 65-66. §-ai. Ennek megfelelóen mind a közalkalmazotti, mind a köztisztviselői szférát magában foglalja az Országos Közszolgálati Érdekegyeztetô Tanács (OKÉT), ahol a kormány az országos szakszervezeti szövetségek és az országos önkormányzati érdekképviseleti szervezetek (városok, megyei városok szövetségei) képviselôivel egyeztet. A szakszervezeti szövetségek képviseletét a szakszervezeti konföderációk látták és látják el ma is. Országos szakszervezeti konföderáción ágazati szakszervezeteket, illetve ágazati szakszervezeti szövetségeket tömörítô, legalább három különbözô ágazatot képviselô munkavállalói érdekképviseleti szervezetet kell érteni.

Az OKÉT 2011 eloott a közalkalmazotti szférát érintốen átfogta és ma is átfogja a Közalkalmazottak Országos Munkaügyi Tanácsát (KOMT), a köztisztviselôi szférát érintốen pedig 2011-ig, vagyis az új Kttv. hatályba léptetéséig az Országos Önkormányzati Köztisztviselôi Érdekegyeztetố Tanácsot. A 2011-ben hatályba lépett Kttv. erôsen centralizációs irányzata a köztisztviselôi érdekegyeztetésnek ezt a rendszerét hatályon kívül helyezte. A 198. § a központi érdekegyeztetés lefolytatására létrehozta a Közszolgálati Érdekegyeztetô Fórumot (KÉF), amely átfogja a központi állami szerveknél és az önkormányzatoknál dolgozó köztisztviselői országos érdekegyeztetést. Az érdekegyeztetés helyi területe pedig a munkahelyi kormányzati érdekegyeztetés lett, amelyet a Kttv. 200-tól 202-ig terjedó szakaszai szabályoznak, kimondva, hogy a köztisztviselôkkel az egyes intézményeken belül az intézményvezető egyeztet.

Ennélfogva az érdekegyeztetés eredeti rendszere csak a közalkalmazotti szférában maradt meg, ahol a KOMT tovább tagolódik ágazati (egészségügyi, közoktatási, felsôoktatási stb.) és területi (megyei) érdekegyeztetố tanácsokra. E tanácsokban az ágazati 
Prugberger Tamás - Rácz Zoltán: A munka-és a közszolgálati jogi érdekérvényesités...

miniszter, illetve államtitkárság, önkormányzati szinten pedig a megyei, illetve a települési önkormányzat egyeztet az ott dolgozó közalkalmazottak reprezentatív szakmai érdekképviseleti és szakszervezeti szerveivel. Reprezentatívnak mind a KOMT, mind pedig az ágazati, alágazati, szakágazati és területi érdekegyeztetési tanácsok esetében azok minôsülnek, amelyek az adott szinten a foglalkoztatottak létszámának 10\%-át tagként bírják, vagy amelyek a munkáltatók legalább 20\%-ában minimum egy ágazatot érintve reprezentatívak (10\%). Országos szinten azt a szakszervezeti szövetséget kell reprezentatívnak tekinteni, amelynek legalább három ágazati szakszervezet a tagja, és tagszervezetei a közalkalmazottak legalább 5\%-át képviselik.

A közalkalmazotti érdekegyeztetésnek ez a reprezentativitási elôírásrendszere jó. Ilyen érvényesült korábban a köztisztviselôi érdekegyeztetés esetében is, amelyet indokolt lenne a közalkalmazotti érdekegyeztetés itt bemutatott előírásai alapján visszaállítani, ismét „visszakapcsolva” az OKÉT-hoz. Ugyanakkor az OKÉT-tel szintén helyes lenne visszakapcsolni az általunk szintén a korábbi formájában visszaállítani javasolt Nemzeti Munkaügyi Tanácshoz, amelynek háromoldalú érdekegyeztetési rendszerét bár 2011-ben formálisan megszüntette a parlament, informálisan azonban a kormány a múlt évtốl kezdve, helyesen, visszaállította. Mint már jeleztük, ez egyértelmúen megmutatkozott az elôzô és az ez évi bértárgyalások során. „De lege ferenda” javaslatainkat jó lenne, ha mihamarabb „de lege lata” jellegú jogalkotás is követné. Ez ugyanis erôsítené azokat a kedvezô politikai-szociológiai folyamatokat, amelyek újból megindultak az állami részvételú megállapodásos érdekegyeztetés irányába, egyrészt a gazdasági életben az állami tulajdon súlyának növekedése okán, az állami érdekeltségú gazdasági cégeket érintve, másrészt a közigazgatás múködésének színvonalemelésével összefüggésben, az állami/önkormányzati foglalkoztató és a foglalkoztatott közhivatalnoki/közalkalmazotti kar egymással szemben támasztott kölcsönös elvárásainak összhangba hozatalát célozva (Lentner-Parragh, 2016:23, 37).

\section{A KOLLEKTÍV (TARIFA-) SZERZŐdÉS}

\section{A gazdasági munkajogban}

Az új Mt. a kollektív szerzódés fogalmával jogdogmatikai jelleggel a gyakorlatra orientálás miatt érthetôen nem foglalkozik. Nem tér ki még látensen sem olyan kérdésekre, mint ami a német munkajogban releváns, és ami a magyar, valamint az osztrák, a frankofón-latin terminológia szerinti ksz.-en nem a szakszervezetek és a munkáltató vagy a szövetségei közötti szerződést érti, hanem azt az átfogó szerzôdésfogalmat, ami a mi kollektív szerzôdésünknek megfelelố tarifaszerzôdést és az üzemi megállapodást fogja át. Ugyanakkor a 276. §-ból, amely a ksz.-kötésre jogosult érdekképviseleti szerveket sorolja fel, kitûnik, hogy kétféle kollektív szerzôdés létezik, melyek közül az egyik a vállalati, vagyis a firma kollektív szerzôdés, a másik az érdekképviseleti szervezetek között megkötendố és vállalati kereteket meghaladó „interorganizációs” kollektív szerződés. Ez utóbbi, a III. fejezetben foglaltak szerint, Magyarországon országos és területi-ágazati, valamint ágazatközi-területi lehet, országos ágazatközi és tripartit jelle- 
gú volt, azonban ez idô szerint az elôzô fejezetben leírtak következtében ma már csak bipartit lehet.

Ami a vállalati ksz. megkötését illeti, munkavállalói és részben munkáltatói oldalt is nézve, az új Mt.-ben van egy negatív és egy pozitív előírás. A negatív az, hogy ksz.-t a munkáltatóval az a szakszervezet is köthet, amely a 10\%-os reprezentativitással a vállalati dolgozók körében rendelkezik [276. § (2) bek. b) pont]. Ha viszont nincs meg a több mint 50\%-os tagsága, egyedül vagy konföderációba lépve egy másikkal, fennáll a veszélye annak, hogy olyan munkavállalókra is kiterjed a ksz., akik annak tartalmával nem értenek egyet. Ezért de lege ferenda vissza kellene állítani azt a korábbi szabályt (a régi Mt. 33. §), mely szerint a szakszervezet egyedül vagy konföderációba lépve csak akkor jogosult a vállalatnál ksz.-t kötni, ha a vállalaton belül 50\%-os reprezentativitással rendelkezik. Ha pedig ez nem áll fenn, akkor a ksz. csak akkor lesz hatályos, ha azt a munkavállalók többségi szavazás mellett jóváhagyják. Addig, ameddig ez az előírás nem kerül vissza az Mt.-be, a bírói gyakorlatnak kellene ezt a megoldást követni, érvénytelennek nyilvánítva az itt említett követelménynek nem megfeleló ksz.-t. Egy ilyen ítélkezési gyakorlat kialakítása azért is fontos lenne, mert a munkáltatónál az új Mt. 276. § (84) bekezdése szerint is csak egy ksz. köthetô. Ezzel kapcsolatosan azonban felvetôdik az, hogy mások a múszakban (termelésben) dolgozó munkások és az irodában munkát végzố alkalmazottak érdekei. Ezért érdemes lenne átvenni a nyugat-európai államok többségének ama gyakorlatát, amely ugyancsak az egy ksz. elvén állva lehetôvé teszi, hogy egy ksz. a munkásokra, egy pedig az alkalmazottakra vonatkozzon.

Az új Mt. 276. § (3) bekezdésének lehetséges egy kedvezô magyarázata a munkavállalókra nézve. E szakasz ugyanis a korábbi Mt.-hez hasonlóan kimondja, hogy ha egy vállalatnál több szakszervezetnek van képviselete, akkor azok együttesen köthetnek ksz.-t. Ez az a szabály, amit jó lett volna tovább részletezni, ilyenkor milyen vállalati reprezentatív lefedettség szükséges. Erre irányult az elóbbi lex ferenda javaslatunk. Azonban a kiinduláshoz visszatérve, helyes magyarázat, hogy olyan szakszervezeti szövetség is részt vehessen a vállalati (firma) ksz. megkötésében, amelynek szakszervezete a vállalatnál reprezentatív, a már kifejtettek szerint azonban nem 10\%, hanem több mint 50\%-ban. Az ellenkezô megoldás ugyanis antidemokratikus és veszélyes is lenne, mert lehetôség nyílna arra, hogy a vállalati vezetés és a szakszervezeti szövetség között létrejövố olyan megállapodást erôltetnének rá a többségre, amelyet az nem akar, sôt ellene van.

A 276. § (6) bekezdése a korábbi Mt.-vel és a német Tarifatörvénnyel egyezôen helytállóan mondja ki, hogy a kollektívszerzôdés-kötésre irányuló ajánlat - bármely fél részérôl is érkezik - nem utasítható vissza. Ugyanezen szakasz (7) bekezdéséból pedig kiviláglik, hogy a német joghoz hasonlóan nálunk is lehetséges a tarifatársaság. Ez kikövetkeztethetố a (7) bekezdés által biztosított lehetôségból, miszerint ha egy szakszervezet a ksz. megkötését követôen felel meg a reprezentativitási feltételeknek, a már megkötött ksz. módosítását kezdeményezheti, és az ezzel kapcsolatos tárgyalásokon javaslattételi joggal már részt vehet. A ksz.-t már megkötött felek azonban a módosításhoz nem kötelesek az ilyen szakszervezet kívánságára hozzájárulni. Ez következik 
Prugberger Tamás - Rácz Zoltán: A munka-és a közszolgálati jogi érdekérvényesités...

a tarifális kötöttség (Tarifgebundenheit) elvébôl. E lehetôség megnyitása azonban a kodifikátor részéról jó ötlet volt.

A 277. § (1) és (2) bekezdésének értelmében a ksz. az individuális (Mt. II. rész) és kollektív Mt. (III. rész) munkajoghoz tartozó bármely kérdést rendezhet, és ennek során a „Günstigkeitsprinzip”, azaz a kedvezôbb hatás elve szerint eltérhet az Mt. rendelkezéseitôl. A kedvezóbb hatás elvébôl fakad, hogy az alacsonyabb ksz. nem lehet kedvezôtlenebb a magasabbnál, csak kedvezóbb a munkavállalók számára. Ezzel függ össze az is, hogy a munkáltatói jogutódlásnál csak akkor nem marad egy évig érvényben a jogelôddel kötött ksz., ha a jogutódé kedvezóbb a munkavállalók részére. Ha kedvezőbb, akkor a jogutódé lép a jogelôd által kötött ksz. helyébe. Hogy a kettố közül melyik a kedvezôbb, azt az egymással összefüggó rendelkezések összehasonlításával kell összességében elbírálni, ami azt jelenti, hogy nem lehet a kedvezóbb pontokat kiválogatva egy új ksz.-t összeállítani.

A ksz. hatályáról a 115. ponton belül a 279. § hagyományos módon kimondja, hogy a ksz. arra a munkáltatóra és annak a munkáltatói szövetségnek a tagjaira terjed ki, akiknek a meghatalmazása alapján azt megkötötte. Ez az előírás nem problematikus, mivel a tarifaképesség fennállása egyértelmú. Nem ilyen problémamentes azonban a munkavállalókra vonatkozó hatály, amirôl már többször is szó esett. Az ugyanis, hogy a szakszervezet mind ágazati, mind vállalati ksz.-t az új Mt. szerint már 10\%-os reprezentativitással megköthet, ha rajta kívül az adott ágazatban vagy vállalatnál (cégnél) nincs képviselete más szakszervezetnek, diktátum lehet a szakszervezeten kívül álló munkavállalókra, ha azok többségben vannak. Ezért elfogadható, hogy az ágazati párbeszédbizottságban és a vállalati érdekegyeztetố tárgyalásokon 10\%-os reprezentativitással rendelkezó szakszervezet részt vehessen, ksz.-t azonban csak egyedül vagy konföderációban 50\%-ot meghaladó reprezentativitás mellett köthessenek. A tarifaképességnek megfelelés csak ilyen reprezentativitás mellett képzelhetô el. A ksz. hatályáról szóló 115. pontnak komoly hiányossága továbbá az is, hogy a korábbi Mt.-vel ellentétben nem szabályozza a ksz. hatósági kiterjesztésének a lehetôségét. E joghézagot lex ferenda szintén pótolni lenne szükséges, mégpedig a korábbi szabályozással egyezốn.

A 116. pont két szakaszban (280-281. §), a korábbi Mt.-vel egyezóen és elfogadható módon mondja ki, hogy a ksz.-t az elsố hat hónapban felmondani nem lehet, azt követôen viszont három hónapos felmondási határidôvel felmondható. Az a szabály is logikus, hogy bármelyik oldalon, ha az összes szerzôdô fél jogutód nélkül megszúnik, a ksz. is érvényét veszti.

\section{A kollektív szerzôdés a közszolgálat területén}

A nyugat-európai államokban a közszolgálati kollektív szerzódés - miként a gazdasági élet vezetố alkalmazottainak az érdekeit védó kollektív szerzódés is - általánosan elfogadott. Magyarországon, ahogy a gazdasági életben ismeretlen a vezetố alkalmazottak érdekeit védô országos és területi ágazati kollektív szerzôdés, amelyeket az ágazati szakszervezeti szövetségek kötnek meg a megfeleló ágazati munkáltatói szövetségekkel, ugyanúgy ismeretlen a hazai köztisztviselôi szférában is. Magyarországon ugyanis 
az 1992. évi Ktv. sem tett említést a köztisztviselôk jogait és kötelezettségeit rendezô kollektívszerződés-kötés lehetôségérôl. Bár akkor is voltak már a köztisztviselôket különbözô csoportok és foglalkozások szerint tömörítô szakszervezetek (mint amilyen pl. a tudományos dolgozók, rendőrök, túzoltók szakszervezetei), amelyek köthettek volna a hatósági intézmények vezetôivel az ott dolgozó köztisztviselóket érintve kollektív szerződést, vagy a kormány ágazatközi, az ágazati miniszter pedig ágazati jelleggel a saját ágazatához tartozó köztisztviselóket érintve. A közszolgálat általában mindkét ágát a tagsági viszony tekintetében átfogó szakszervezetek azonban a Ktv. 1992-ben történt hatálybalépése után informális jelleggel meg tudtak állapodni a kormánnyal abban, hogy a kormány a szakszervezetekkel együtt kollektív szerzôdésben rendezi mindenekelőtt a köztisztviselói illetményeket. Mivel azonban a Ktv. nem szólt a köztisztviselók kollektív szerzôdéseiról, ezért a szakszervezetek ahhoz ragaszkodtak, hogy az érdekegyeztetés során megkötött megállapodások tárcaszintú rendeletekben kerüljenek nyilvánosságra. Ezzel szemben a nyugat-európai államokban az országos ágazatközi és ágazati közhivatalnoki kollektívszerzôdés-kötés bevett gyakorlat a közszolgálat területén, ami megtalálható a területi és a települési önkormányzatoknál is (LentnerParragh, 2016:25-26).

Mindezt figyelembe véve, indokolt lenne a Kttv.-ben is nemcsak a köztisztviselói érdekegyeztetést, hanem a köztisztviselói kollektív szerzôdést is rendezni, mégpedig a Kjt.-ben szabályozott kollektív szerzôdés alapulvételével. Azonban mind a két helyen indokolt lenne a Kjt. 13. §-ába foglalt megszorítást kiiktatni. E megszorítás szerint ugyanis a törvénytôl és egyéb jogszabályoktól a közalkalmazotti kollektív szerzôdés csak akkor térhet el, ha erre a jogszabályok kifejezett felhatalmazást adnak. Itt tehát nem érvényesül a kedvezményezés (Günstigkeitsprinzip) elve, melynek értelmében, ha a kollektív szerzôdésbe foglalt megállapodás kedvezôbb a jogszabálynál vagy a magasabb kollektív szerzôdésnél, akkor az eltérésre lehetôség van. Az itt bemutatott megszorítással viszont a közalkalmazotti kollektív szerződés értelmét veszti. Jogszabály meghozatalával ugyanis bármikor, akár teljesen elejét lehet venni annak, hogy kollektív szerzôdés rendezze a közalkalmazottak közszolgálati viszonyát.

\section{A KOLLEKTÍV MUNKAÜGYI VITA}

A kollektív munkaügyi vita a köztisztviselői jogban nem létezik, csak a gazdasági munkajogban és a közalkalmazotti jogban, mely utóbbinál is az Mt. szabályai szerint kell eljárni. A kollektív munkaügyi vitának két csoportja létezik. Az egyik a kollektív munkaügyi jogvita, amelyet $A$ munkajogi igény érvényesítése címú fejezet az individuális munkaügyi jogvitával együtt rendez, míg a kollektív munkaügyi érdekvitáról szóló másikat A kollektív munkaügyi vita címú XXIII. fejezet szabályozza, mellesleg megjegyezve, hogy ez utóbbi fejezetcím megfogalmazása pontatlan, mivel hiányzik belóle az érdek szó.

Ami a kollektív jogvitákat illeti, az új Mt. 289. §-a is rövid határidóvel, „5 napon belül” a munkaügyi bírósághoz benyújtandó és 15 napon belül zárt tárgyaláson elbírálandó eljárást ír elô, amelyen hozott határozattal (ítélettel) szemben szintén „5 napon belül” van helye fellebbezésnek, amelyet a másodfokú bíróságnak „15 napon 
Prugberger Tamás - Rácz Zoltán: A munka-és a közszolgálati jogi érdekérvényesités...

belül” kell elbírálnia. Magával a konstrukcióval szemben kifogás nem merül fel, csupán a határidốk rövidsége és pontatlan meghatározása vitatható, már csak amiatt is, mivel a korábbi nyolcnapos határidôk öt napra történô lerövidítése ellentétes a polgári perrendtartással, ahol a peres és a nemperes alaki jogi jellegú pervezetési határidôk egyöntetúen nyolcnaposak. Mivel kollektív munkajogi vitát a 289. § és a sztrájktörvény szerint nemcsak a szakszervezet és az üt., hanem a munkáltató is indíthat, az ötnapos határidô - még akkor is, ha igazolási kérelemnek helye van - túlságosan rövid. Ezért helyes lenne, ha a bírói gyakorlat az „öt napot” öt munkanapként értékelné, amelybe a vasár- és ünnepnapok mellett a szombat sem számítana bele. Ugyanezt a megoldást lenne helyes alkalmazni a bíróságok 15 napos elbírálási határidejénél is azzal, hogy a határidố kezdete az elbíráló tanács részére történô kiszignálás és kézhezvétel napja.

Áttérve a kollektív munkaügyi érdekvitákra, a 291-293. §-ok rendelkezései szerint a német megoldás átvételével, az egymással vitában álló felek (munkáltató és szövetségei, valamint a szakszervezet és szövetségei, továbbá az üzembirtokos és az üzemi tanács) a közöttük felmerüló viták feloldására egyeztetố bizottságot alakíthatnak. Az egyeztetố bizottságba a munkáltatói és a munkavállalói érdekképviseleti oldal azonos számban delegál tagokat, míg az elnök személyének függetlennek kell lennie. Az elnök személyéról a vitatkozó feleknek közösen kell megállapodniuk. Az egyeztetési eljárás során az elnök köteles a két fél által delegált tagokkal folyamatosan konzultálni, akiknek segítségével tudja megfelelő objektivitás mellett kialakítani az álláspontját. Az egyeztetési eljárást annak befejezésekor jegyzőkönyvbe kell foglalni, eredményesség és eredménytelenség esetén egyaránt. Eredménytelenség esetén a bizottság felajánlhatja az arbitrálást, vagyis a döntéshozatalt akkor, ha a felek az ezt követôen döntôbizottsággá átalakuló bizottság döntését előzetesen elfogadják. Szavazategyenlôség esetén a döntôbizottság elnökének a szavazata dönt. Nem szerepel az Mt.-ben, azonban ez a döntés közjegyzői úton végrehajthatóvá válik.

Az új Mt. ezzel a szabályozással továbbfejlesztette és precízebbé tette azt az alulról építkezô kötetlen rendszert, amelyet a korábbi Mt. alakított ki. Ugyanakkor ez a rendszer azért nem tudott korábban kibontakozni, mivel angolszász mintára 1997-ben háromoldalú (tripartit) kollektív megállapodással kialakították a Munkaügyi, Közvetítô és Döntốbírói Szolgálatot (MKDSZ), amely az OÉT mellett múködött, és az angol ACAS-hoz hasonlóan ${ }^{10}$ egyszemélyes közvetítői, egyeztetôi és döntôbírói eljárásként alakult meg. Azonban az egymással vitatkozó felek a szolgálatot alig vették igénybe, mivel a szolgálat egyeztetố és döntốbíró tagjai számára - ellentétben az angol-amerikai rendszerrel - nem írták elố követelményként a mindkét oldalú érdekvédelmi szervektôl, valamint a munkáltatótól és a munkavállalótól való függetlenséget. Emiatt szinte minden szakszervezeti és munkáltatói szövetségi vezetố a szolgálat tagjává vált. Ezenkívül az egy személy által, vagyis az egyeztetố vagy a döntóbíró (arbitrátor) által egyedül vezetett egyeztetésnél, valamint arbitrálásnál nem kapott az egyeztetó és a döntôbíró tanácsot a vitatkozó felek delegáltjaiból összeálló bizottságtól. E két körülmény miatt a vitatkozó felek a Szolgálatot alig keresték meg, és alig vették igénybe egyeztetésre és arbitrálásra. Mindez arra utal, hogy az angolszász rendszernél a kontinentális bizottsági rendszer jobb. Ennélfogva helyesen döntött az új Mt. megalkotója 
akként, hogy a kontinentális európai bizottsági rendszert és annak nem a felülrôl épülô, kötött frankofón, hanem a kötetlen germán formáját választotta. Ezzel párhuzamosan az MKDSZ sorvadásnak indult, majd 2016-ban megszúnt. Transzformálva azonban mégis megmaradt, azóta ugyanis a szerepét a Munkaügyi Tanácsadó és Vitarendezô Szolgálat vette át, amely konzorciumi (szakszervezetek és az NGM) háttérrel tevékenykedik. Egyelôre azonban még a kifutásának eredményessége nem prognosztizálható.

A közszolgálati vitarendezésnél a legnagyobb probléma azonban az, hogy a Kttv. 195. $§(1)$ bekezdése szerint a jogszabály meghatározza a munkaügyi konfliktusok megelôzésére, feloldására irányuló eljárást, de valójában erre nem kerül sor a törvényben. Indokolt lett volna a nemzetközi munkaügyi szabályokkal és az Mt.-vel összhangban szabályozni az egyeztetés, közvetítés, kötelezô döntôbíráskodás lehetôségét a köztisztviselôi szférában is. Ezen szabályozási hiány miatt a köztisztviselôi szféra a munkajogi érdekkonfliktusok megoldására vonatkozó szabályrendszer nélkül marad, ami különösen a sztrájkjog korlátozottsága miatt jelent súlyos problémát.

\section{A MUNKAKÜZDELEM}

Nem lenne teljes a kép, ha nem érintenénk a kollektív munkajog utolsó intézményeként a munkaküzdelmet, amely a kollektív tárgyalások és a kollektív megállapodások meghiúsulása esetén a nyomásgyakorlás utolsó eszköze mind a két oldalról, a megegyezés érdekében. Annyit jegyzünk meg, hogy a munkaküzdelemrôl szóló, az 1989:VII. tv.-ben megfogalmazott, ma hatályos jogi szabályozás hiányos, mivel csak a sztrájkról szól, a munkáltató nyomásgyakorlási eszközérôl, a kizárásról (lock out/ Aussperrung) viszont egy szót sem szól. Míg a sztrájk esetében a munkavállalók nem hajlandók dolgozni, addig a kizárás esetében a munkáltató nem engedi a munkavállalókat dolgozni, és kizárja ôket a munkahelyrôl. A nyugat-európai országokban, Németország kivételével, csak az ún. védekezó kizárás a jogos. Ez azt jelenti, hogy a kizárás csak törvénytelen vagy jogszerútlen sztrájk esetében alkalmazható védekezésképpen abból kiindulva, hogy a munkavállaló a gyengébb fél. Sót Portugáliában a lock out egyáltalán nem alkalmazható. Magyarországon a kizárást semmilyen jogi norma nem zárja ki, és nem is korlátozza. Ezért az ún. támadó lock out is alkalmazható, amit legfeljebb a rendeltetésszerú joggyakorlásra vonatkozó szabállyal lehetne korlátozni. Erre is helyes lenne kúriai állásfoglalást hozni. Még inkább azonban e jogintézmény törvényi szabályozása volna indokolt, amit össze lehetne kapcsolni a sztrájkjogi szabályozás korszerúsítésével.

Ami a közszolgálatban dolgozók sztrájkszervezési és sztrájkban való részvételi jogát illeti, kétféle szabályrendszer alakult ki Európában. A liberális irányvonalat Franciaország és az Egyesült Királyság képviseli. Franciaországban a közszolgálat kinevezett munkatársai is sztrájkolhatnak, kivéve a hadsereg tagjait és a magas rangú közhivatalnokokat. Az 1968-as diáklázadással kezdôdött országos kiterjedésú általános sztrájkot Charles de Gaulle úgy tudta letörni, hogy államelnöki minôségében, mint a hadsereg főparancsnoka, elrendelte a sztrájk kulcsfiguráinak katonai behívását (A XX. század krónikája, 1994). Az Egyesült Királyságban még ilyen korlátozás sincs. ${ }^{11}$ A közszolgá- 
lat dolgozói éppen úgy sztrájkolhatnak, mint a gazdasági élet munkaviszonyban álló dolgozói. Azonban mindkét területen be kell tartani a „case law” által a munkaküzdelemre kialakított „aranyformula” (golden formel) szabályait (Horion, 1966; Radnay, 1990:32-40). A másik irányvonal a germán szabályozás, ahol minden közhivatalnok részérôl tilos a sztrájk. ${ }^{12}$ Éppen ezért, hogy a mozdonyvezetốk ne tudják megbénítani a vasúti közlekedést sztrájkkal, a mozdonyvezetôket - mindaddig, amíg a Deutsche Bahn köztestületként múködött - közhivatalnoki státuszba (Beamte) sorolták be. ${ }^{13}$

Az 1989:VII. tv., a Sztrájktörvény e két szélsố álláspont között egy középutas megoldást alakított ki. E szerint a Kjt. hatálya alá tartozó közalkalmazottak, a munkavállalókhoz hasonlóan, az e törvényben lefektetett elôírások figyelembevételével éppúgy sztrájkolhatnak, mint a munkavállalók. A kinevezett közalkalmazottak esetében azonban tilos a sztrájk. Ezt a korlátot megítélésem szerint helyes továbbra is fenntartani. Kérdéses lehet azonban, hogy a munkaszerzôdéssel, nem pedig kinevezéssel alkalmazott közhivatalnokokra és az ügykezelókre is kiterjed-e ez a tilalom. Álláspontom szerint nem, mivel a szerzódéses közhivatalnokok, még ha a gyakorlatban hasonló státuszbiztonságot is élveznek, mint a kinevezett köztisztviselők, ez azonban „de jure” rendezve nincs, csak „de facto” áll fenn. Az ügykezelôk pedig effektíve nem köztisztviselôk. A köztisztviselók esetében a sztrájkjog gyakorolható ugyan, de jelentôs korlátozásokkal. A Sztrájktörvény 3. § (2) bek. II. fordulata értelmében az államigazgatási szerveknél a kormány és az érintett szakszervezetek megállapodásában rögzített szabályok mellett gyakorolható a sztrájk joga. Az 1993-ban kötött megállapodás több helyen is ellentétes az Alaptörvénnyel, a sztrájktörvénnyel és a nemzetközi dokumentumokkal.

\section{ÖSSZEGZÉS}

Tanulmányunkban igyekeztünk a kollektív munkajog érdekegyeztetés területével kapcsolatos részének valamennyi intézményét átfogó jelleggel megvizsgálni. Sajnálatos, hogy a 2010-2012. évi magyar jogalkotás és jogpolitika a nyugat-európai joggal ellentétben háttérbe szorította e jogintézményt, és az üzemi tanácsot helyezte elótérbe, amit a 2012. évi új Mt.-nek a korábbival szembeni szabályozásisorrend-felcserélése is mutat. Ugyanakkor örvendetes, hogy ismét kezd visszaállni a jelentôsége, amire utal az is, hogy a jogi szakirodalmon túlmenôen a közgazdaságtani szakma is foglalkozik ezzel az intézménnyel. A Lentner és Parragh szerzôpáros kutatása kiterjed a participációra, vagyis az üzemi tanácsi rendszerre is (Lentner-Parragh, 2016:25-26), mely intézménnyel a késôbbi számban kívánunk majd foglalkozni.

\section{JEGYZETEK}

1 A tanulmány a Nemzeti Kutatási Fejlesztési és Innovációs Hivatal támogatásával (K120158 kutatási témapályázat keretében) az NKFI Alapból valósult meg.

2 Lásd továbbá Jura Europae, 1993, I. 30-00. /I.1.19-22/ és 30.50. I.3. (Fr.); II.60.50-8. / III.4./ (NL.) III.60.50.-8 /I.3-4./ (DM.: Functionarlowen-FUL); 40.00-7. és 40.50-7 /VI. I.18./ (I.).

3 Jura Europae, 1993, I. 30-60 (Fr.); III. 90-60.1-11. (GB.); I. 10-60. I. (D.). 
4 1992:XXXII. tv. a közalkalmazottak jogállásáról (utolsó átf. mód. 2011-ben) - 1992. XXII. tv. a köztisztviselôk jogállásáról, majd helyette 2011:CXCIX. tv. a közszolgálati köztisztviselôkrôl. A magyar duális szabályozás kritikai összefoglalását és kritikáját unikális javaslatot felvázolva adja Prugberger, 2010.

5 Vö. a 2010-ben módosított 1989. VII. tv.-nyel.

6 Jura Europae, 1993, 30. 51. I. 2. (Fr.).

7 Jura Europae, 1993, I-III. 20-90. 5-2. etc.

Jura Europae, 1993, 60.51. III. (NL.).

9 Erre mondja a Lentner és Parragh szerzôpáros, hogy az érdekegyeztetés fokozatosan a háromoldalúról a kétoldalúra csúszott át (Lentner-Parragh, 2016:34), ami valóban így is van. Ugyanakkor helyesen szól arról is, hogy az érdekegyeztetésnek gyakran nemzetgazdasági és nemzetállami szintú kihatása is van, ami bekövetkezhet pozitív és negatív eredménnyel egyaránt (Lentner-Parragh, 2016:27). E megállapítás is amellett szól, hogy a háromoldalú országos munkaügyi érdekegyeztetés és megállapodás - éppen úgy, mint az e körön túlmenô is - igen jelentôs és nem kiiktatandó jogintézmény.

10 Jura Europae, 1993, III. 90.60.11-22. és 70.11-12.

11 Vö. Prugberger-Nádas, 2015:171, 174-177.

12 Jura Europae, 1993, 30.60-1-18.(Fr.); 90.60-1-11.GB.; 10-10.60.I (D.).

13 Információ Prof. Dr. Dres. h.c. Rolf Birktôl, az IAAEG igazgatójától.

\section{FELHASZNÁLT IRODALOM}

A XX. század krónikája (1994). Officina Nova Kiadó, Budapest.

Heerma van Voss, G. J. J. (2011): Inleiding Nederlands sociaal recht. Boom Juridische uitgevers, Den Haag.

Horion, Paul (1966): Le droit de grève. R. C. J. B., Charleroi.

Jura Europae. Droit du Travail - Arbeitsrecht (1993). Editions Techniques Juris Chasseurs - C. H. Beck Verlag, Paris-München.

Lentner Csaba - Parragh Bianka (2016): Érdekegyeztetés, konszenzuskeresés és participáció - új dimenziók, állami attitúdök. Pro Publico Bono - Magyar Közigazgatás, 2. sz., 26-40.

Ojeda Aviles, Antonio - Perez, Manuel (1989): Gewerkschaftsrechte im Betrieb nach spanischem Recht. Arbeitsrecht im Betrieb, No. 12.

Peine, Franz-Josef - Heinlein, Dieter (1999): Beamtenrecht. 2. Aufl., Schaefers Grundriss des Rechts und der Wirtschaft. C. E. Müller Verlag, Heidelberg.

Prugberger Tamás (2010): A széttagolt magyar közszolgálati jogi szabályozás egységesítésének kérdése a nyugat-európai megoldások tükrében. Publicationes Universitatis Miskolcinensis, Sectio Juridica et Politica, Tomus 28, No. 1, 437-461.

Prugberger Tamás - Nádas György (2015): Európai és magyar összehasonlító kollektív munkajog. Wolters Kluwer Kiadó, Budapest.

Prugberger Tamás - Szebehelyi Klára (1996): A magyar munkajog vergôdése az európai uniós normák és a liberálkapitalizmus igényei között. Jogtudományi Közlöny, 51. évf., 12. sz., 509-518.

Radnay József (1990): A sztrájk egyes kérdései a külföldi jogrendszerekben. Munkaügyi Szemle, 5. sz.

Söllner, Alfred (1969): Arbeitsrecht. Kohlhammer, Stuttgart.

Sredkova, K. (1995): Das bulgarische Arbeitgesetzbuch auf dem Wege der Reformen. Zeitschrift für Internationale Arbeits- und Sozialrecht (ZIAS), No. 2. 